\title{
Inflammatory Pseudotumor of the Urinary Bladder Mimicking Bladder Cancer Secondary to Diverticulitis of the Sigmoid Colon
}

\section{Sigmoid Kolon Divertikülüne Sekonder Gelișen Mesane Tümörünü Taklit Eden Mesanenin Enflamatuvar Psödotümörü}

\author{
Tarık Yonguç MD1, Burak Arslan MD2, İbrahim Halil Bozkurt MD1, Salih Polat MD1, Serkan Yarımoğlu MD1, Süleyman Minareci MD1 \\ ${ }^{1}$ Bozyaka Training and Research Hospital, Clinic of Urology, Istanbul, Turkey \\ 2Haseki Training and Research Hospital, Clinic of Urology, Istanbul, Turkey
}

\begin{abstract}
Summary
A case of inflammatory pseudotumor of the urinary bladder secondary to diverticulitis of the sigmoid colon without colovesical fistula was reported. The patient was admitted with suprapubic sensibility and dysuria. Computerized tomography (CT) strongly suggested a bladder tumor with invasion of the rectum. We performed partial cystectomy and partial colectomy. Histological examination revealed an inflammatory pseudotumor together with diverticulum of the sigmoid colon. This diverticulum may have ruptured to cause the inflammatory pseudotumor of the bladder.
\end{abstract}

Key Words: Inflammatory pseudotumor, bladder tumor, diverticulitis of the sigmoid colon
Özet

Sigmoid kolon divertikülüne sekonder gelişmiş henüz mesaneye fistülize olmamış, mesanenin psödotümörü olgusu sunuldu. Hasta kliniğimize suprapubik hassasiyet ve dizüri ile başvurdu. Bilgisayarlı tomografide (BT) rektuma invazyon gösteren, mesane tümörünü düşündüren kitle tespit edildi. Hastaya parsiyel sistektomi, parsiyel kolektomi uygulandı. Histolojik değerlendirmede sigmoid kolon divertikülüyle birlikte inflmatuar psödotümör histolojisi gözlendi. Biz bu divertikül rüptürünün mesanede inflamatuar psödotümöre neden olduğu düşündük.

Anahtar Kelimeler: Enflamatuvar psödotümör, mesane tümörü, sigmoid kolon divertiküliti

\section{Introduction}

Pseudotumors of the bladder are uncommon and sometimes misdiagnosed as real tumor. We reported such a case caused by diverticulitis of the sigmoid colon without fistula which was suspected a colon or bladder cancer even after computed tomography and cystoscopy.

\section{Case Report}

Fifty-seven years old man patient was admitted to our clinic with suprapubic tenderness and dysuria. Urinary ultrasonography showed the lesion that extending to the bladder lumen from the left wall. Urinary cytology was negative. Cystoscopy detected a tumor with smooth surface at the same localization. CT showed $40 \times 14 \mathrm{~mm}$ size solid contrast enhancing mass which is containing air density on the bladder left lateral wall (Figure 1).

Colonoscopy demonstrated multiple diverticula orifices with inflamatory change on the mucosa. Exploration was planned to confirm primer disease. We observed at the level of the inferior segment of the sigmoid colon strongly adherent to urinary bladder. After we subsequently performed partial cystectomy, partial colectomy and colostomy (Figure 2).

Pathological examination revealed no malignancy. It's reported as chronic inşammation in the suburothelial connective tissue and localised peritonitis due to perforation of diverticulum of sigmoid colon. Follow-up with CT scan 6 months postoperatively was normal and showed no evidence of recurrence.

\section{Discussion}

Inşammatory pseudotumor (IPT) of the genitourinary tract is a rare lesion (1) and first described by Roth (2) in 1980 in a female patient presenting with recurrent cystitis. Radiological imaging usually detect a bladder mass without metastasis $(3,4)$. The etiology of this disease is not known. Lopez-Beltran et al. (5) have asserted that inflammatory pseudotumor is induced by proliferative cystitis because most reported cases showed 


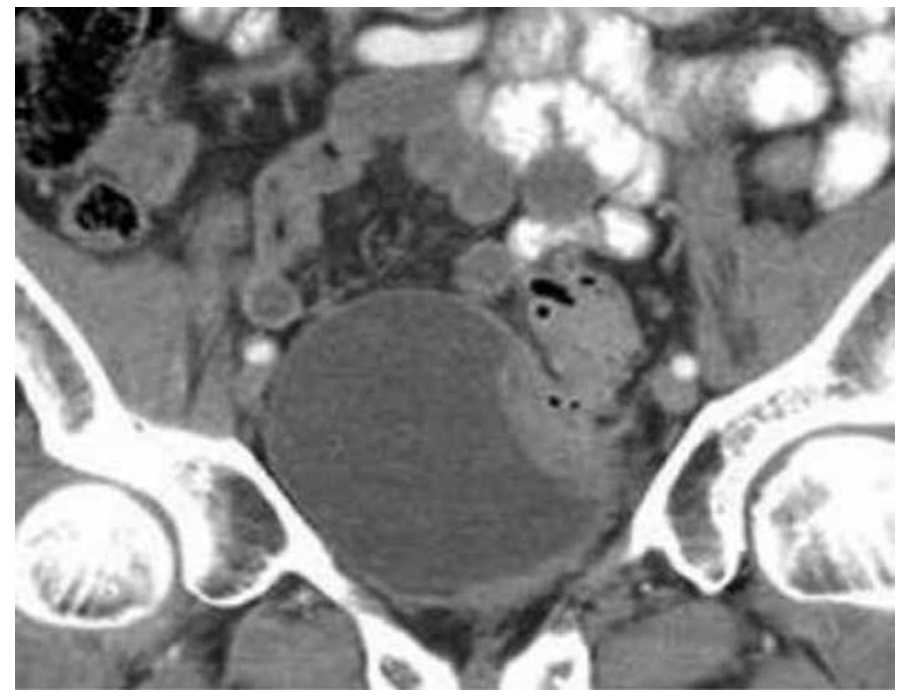

Figure 1. 40×14 mm size solid contrast enhancing mass which is containing air density on the bladder left lateral wall

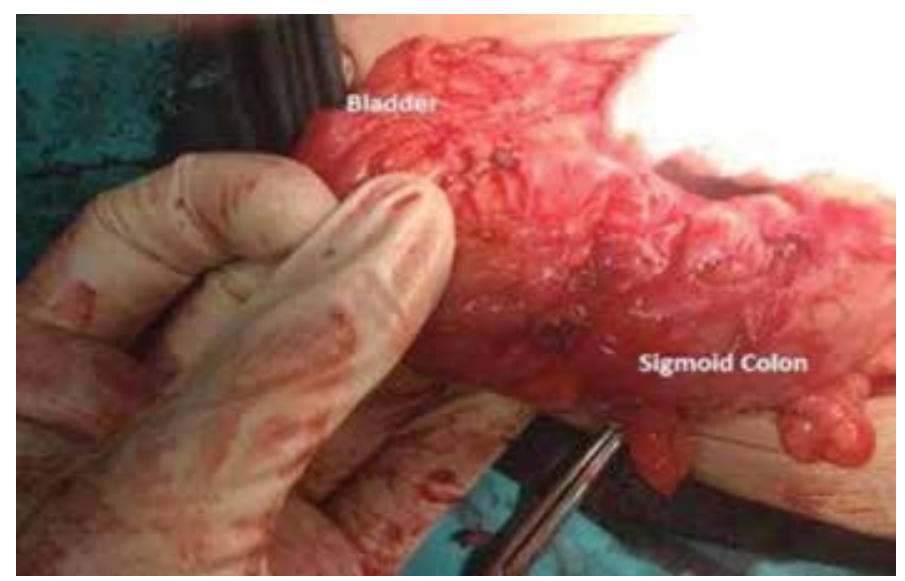

Figure 2. Level of the inferior segment of the sigmoid colon strongly adherent to urinary bladder lateral wall

non-neoplastic proliferation of fibroblasts/myofibroblasts on a background of proliferating vessels. Interestingly, a diverticulum of the sigmoid colon was found in the middle of the pseudotumor in our case. In most cases, inflammatory pseudotumors are caused by chronic infection and/or inflammation of the bladder (3). In our case, probably that chronic inflammation due to perforation of the diverticulum might have induced the inflammatory pseudotumor of the bladder.

Hematuria is the most common presenting complaint, although dysuria, frequency, and suprapubic pain have also been reported (6).

Although IPT is benign nature tumor, treatment is very important. Possible pathologies must be revealed before treatment because of proximity with sigmoid colon. Otherwise possible complications such as fistula may lead to sepsis. Transurethral resection or partial cystectomy has been reported as the treatment of choice. However, we suggest that transuretral resection should not be performed because of sepsis complication due to sigmoid colon fistula. In these cases we suggest that partial cystectomy is as optimal treatment with minimal morbidity. Complete local resection is sufficient for recurrence-free disease. Therefore should be avoided radical cystectomy IPT of urinary bladder due to diverticulitis of the sigmoid colon has been reported in the literature. It's thought recurrent inflammatory reaction stimulates undifferentiated stromal cells into forming granuloma. It's very difficult to discriminate between a true neoplasm and a postinflammatory pseudotumor. Open surgery should be performed instead of transurethral surgery because of complications in the treatment of inflammatory pseudotumor.

Informed Consent: Consent form was filled out by all participants, Concept: Tarık Yonguç, Burak Arslan, Design: Tarık Yonguç, İbrahim Halil Bozkurt, Salih Polat, Burak Arslan, Data Collection or Processing: Salih Polat, Serkan, Yarımoğlu, Analysis or Interpretation: Tarık Yonguç, Süleyman Minareci, Literature Search: Salih Polat, Serkan Yarımoğlu, Writing: Tarık Yonguç, Salih Polat, Süleyman Minareci, Peer-review: Internal peer-reviewed, Conflict of Interest: No conflict of interest was declared by the authors, Financial Disclosure: The authors declared that this study has received no financial support.

\section{References}

1. Cerrud L, Pimentel E, De Gracia A, et al. Rev Med Panama 2002;27:34-36.

2. Roth JA. Reactive pseudosarcomatous response in urinary bladder. Urology 1980;16:635-637.

3. Jones EC, Clement PB, Young RHInflammatory pseudotumor of the urinary bladder. A clinicopathological, immunohistochemical, ultrastructural, and flow cytometric study of 13 cases. Am J Surg Pathol 1993; 17:264-274.

4. Dietrick DD, Kabalin JN, Daniels GF Jr, et al. Inflammatory pseudotumor of the bladder. J Urol 1992;148:141-144.

5. Lopez-Beltran A, Lopez-Ruiz J, Vicioso L. Inflammatory pseudotumor of the urinary bladder. A clinicopathological analysis of two cases. Urol Int 1995;55:173-176.

6. Iczkowski KA, Shanks JH, Gadaleanu V, et al. Inflammatory pseudotumor and sarcoma of urinary bladder: differential diagnosis and outcome in thirty-eight spindle cell neoplasms. Mod Pathol 2001; 14:1043-1051.

7. Choi SK, Choi YD, Cheon SH, et al. Inflammatory pseudotumor of the urinary bladder in a child. Yonsei Med J 2000;41:401-403.

8. Gugliada K, Nardi PM, Borenstein MS, Torno RB. Inflammatory pseudosarcoma (pseudotumor) of the bladder. Radiology 1991; 179:66-68. 